\title{
Stages of hydropic vacuolation in the liver of winter flounder Pleuronectes americanus from a chemically contaminated site ${ }^{1,2}$
}

\author{
Michael J. Moore*, Roxanna M. Smolowitz**, John J. Stegeman \\ Biology Department, Woods Hole Oceanographic Institution, Woods Hole, Massachusetts 02543, USA
}

\begin{abstract}
Hydropically vacuolated hepatic epithelia are abnormal cells prevalent in winter flounder from chemically contaminated habitats. These cells often have been associated with certain hepatic neoplasms. Here we define the 3 stages of the lesion and show an age and length-specific progression of each stage. The first cells to undergo vacuolation are centrotubular preductular cells. Intermediate stages involve entire hepatic tubules, and advanced stages consist of grossly visible foci of vacuolation that often encapsulate neoplastic foci. Vacuolation was found in fish from Boston Harbor, Massachusetts, USA, that were maintained on clean food and in clean water for $5 \mathrm{mo}$. These data are consistent with vacuolation being a persistent condition. The early involvement of preductular cells, possibly oval cell equivalents, the likely persistence of hydropic vacuolation after chemical exposure, and the close association of vacuolation to neoplastic foci, are consistent with suggestions that vacuolated cells may be linked to hepatocarcinogenesis in these fish. Definition of 3 distinct stages of hydropic vacuolation suggests that the prevalence of each lesion stage may reveal temporal and spatial trends in environmental health in winter flounder and possibly other fishes.
\end{abstract}

KEY WORDS: Hydropic vacuolation - Flounder - Boston Harbor - Environmental carcinogenesis

\section{INTRODUCTION}

Neoplasms and other cellular abnormalities in the liver of winter flounder from chemically contaminated sites in Boston Harbor, Massachusetts, USA, were first described in 1985 (Murchelano \& Wolke 1985). That report also contained the first description of a condition later called hydropic vacuolation (Moore 1991, Johnson et al. 1993) characterized by cells with large nonstaining vacuoles and small peripheral nuclei. Studies have confirmed the high prevalence of this condition in winter flounder (Johnson et al. 1993, Moore et al. 1996), and a similar condition in other species (Myers et al. 1994). The prevalence of hydropic vacuolation has been shown to be statistically correlated with exposure of winter flounder, starry flounder and white

\footnotetext{
•E-mail: mmoore@whoi.edu

- Present address: Laboratory for Aquatic Animal Medicine and Pathology, Univ. of Penn, Marine Biological Laboratory, Woods Hole, Massachusetts 02543, USA
}

croaker to chlorinated hydrocarbons, especially pesticides such as the chlordane and DDT groups (Johnson et al. 1992, Myers et al. 1994, Moore et al. 1996). Foci of hydropic vacuolation are also intimately associated with neoplasia in winter flounder (Murchelano \& Wolke 1985, Moore \& Stegeman 1994), suggesting that such cells may be involved in carcinogenesis resulting from chemical insult. The prevalence of these lesions might thus be considered for estimating temporal and spatial chronic toxic risks in vertebrates exposed to marine food and water resources.

Before the lesions can be used in environmental assessment the different stages of the condition as briefly described in an earlier short communication (Moore et al. 1989) must be fully defined. The cells involved at each stage need to be identified. Classifi-

\footnotetext{
${ }^{1}$ In memory of Clyde Dawe

${ }^{2}$ An abstract and a short communication of posters at 2 meetings describing part of this work have been published previously (Moore et al. 1989, Moore \& Stegeman 1990)
} 
cation of each stage will further our understanding of these lesions and associated tumors. In a previous report (Bodammer \& Murchelano 1990) the issue of whether hydropic vacuolation involves cholangiocytes, hepatocytes or both was discussed but remained unresolved. Moreover, lesion prevalence and severity associated with age, gender and reproductive status have not been described. Similarly, whether continued exposure is required for the persistence of hydropic vacuolation is not known.

Here we employed light and electron microscopy to examine the progression of hydropic vacuolation in winter flounder from Boston Harbor. The ultrastructure of normal winter flounder and of one stage of hydropic vacuolation, defined in the present study as tubular vacuolation, has been described (Bodammer \& Murchelano 1990). In this study a larger number of fish were examined to establish a classification describing different stages in the context of the structure of the teleost liver. Three stages of hydropic vacuolation are defined, with sequential involvement of biliary epithelia and hepatocytes. We show the prevalence of these 3 stages to increase sequentially with increasing age and length of fish exposed to contaminated sediments.

\section{MATERIALS AND METHODS}

Sample collection and preparation. Winter flounder Pleuronectes americanus examined in this study were from 3 locations:

(1) Deer Island Flats, Boston Harbor: this site has been chronically and severely contaminated with organic pollutants including polynuclear aromatic and halogenated hydrocarbons, and a diversity of heavy metals (Johnson et al. 1993). Fish were obtained from Deer Island Flats by trawl or by hook and line. Altogether 334 adults and 71 young of the year were taken from Deer Island between 1987 and 1990.

(2) Georges Bank: a relatively uncontaminated offshore site in the NW Atlantic (Boehm \& Hirtzer 1982). Adult fish from Georges Bank were obtained by trawl. Seven adults caught in 1989 from an area bounded by the lines $40^{\circ} 52^{\prime} \mathrm{N}, 41^{\circ} 41^{\prime} \mathrm{N}, 71^{\circ} 42^{\prime} \mathrm{W}$ and $67^{\circ} 29^{\prime} \mathrm{W}$. Histological slides of liver tissue from an additional 50 adults caught in 1985 in this same area were examined from the New England Aquarium (Boston, MA, USA) slide archive.

(3) Scorton Creek: a relatively uncontaminated (Moore et al. 1995) marsh system on Cape Cod, Massachusetts. Ten young of the year were taken by beach seine from this site in 1988 and examined histologically.

Between 1 and 48 h after capture adult fish were measured and killed by cervical section. The gender was recorded and the livers were removed and serially sliced at $4 \mathrm{~mm}$, as described previously (Moore 1991). Young of the year fish were not dissected, except for an incision into the peritoneal space to allow influx of fixative to the viscera. Animal holding and euthanasia conformed with protocols approved by the Woods Hole Oceanographic Institutional Animal Care and Use Committee.

In April 1987, 52 adults collected by trawl from Deer Island Flats were returned alive to Woods Hole, and held in $90 \%$ recirculated Woods Hole seawater, at a temperature of between 8 and $15^{\circ} \mathrm{C}$ at a bottom density of 10 fish $\mathrm{m}^{-2}$. Fish were held under these conditions for 5 mo before sampling. These fish were fed chopped surf clams from Georges Bank, a relatively unpolluted site, at a ration of approximately $2 \%$ body weight per day. Analysis by gas chromatograph-mass spectrometry of a subsample of the clams from this site showed total Arochlor 1254 to be $25 \mathrm{ng} \mathrm{g}^{-1}$ dry weight (E. Monosson pers. comm.).

Light microscopy. Liver slices from adults and whole young of the year were fixed in $10 \%$ neutral buffered formalin. Young of the year were decalcified for $48 \mathrm{~h}$ in saturated versenate. Samples were then processed routinely for paraffin embedding, sectioned at $5 \mu \mathrm{m}$ and stained with hematoxylin and eosin. Selected sections were stained also for glycogen by the periodic acid Schiff (PAS) method of McManus (Luna 1968), and for iron (Luna 1968).

The prevalences of the following lesions were recorded using a Zeiss Axioskop: (1) Vacuolation, seen in 3 stages: (a) Centrotubular vacuolation; isolated groups of 1 or 2 vacuolated cells in the center of the hepatic tubule). (b) Tubular vacuolation; linear arrays of vacuolated cells, filling the hepatic tubule, often extending into biliary duct structures. (c) Focal vacuolation; foci of 30 to several hundred contiguous vacuolated cells. (2) Macrophage aggregation. (3) Biliary duct proliferation. (4) Neoplasia (hepatocellular and cholangiocellular lesions were distinguished as described previously (Moore \& Stegeman 1994). (5) Necrosis.

Electron microscopy. Liver from 18 of the adult fish was also examined ultrastructurally. Subsamples of 3 visibly normal liver slices from each individual, and of slices from representative grossly abnormal lesions were selected for ultrastructural analysis. Samples were trimmed and diced into $1 \mathrm{~mm}$ cubes in an ice cold drop of modified Karnovsky's fixative (Ito \& Karnovsky 1968 ) (2\% formaldehyde, $2.5 \%$ glutaraldehyde, $0.1 \mathrm{M}$ cacodylate, $\mathrm{pH} 7.2$ ) and then held in the fixative on ice for 12 to $24 \mathrm{~h}$. Chemicals and materials for electron microscopy were obtained from Electron Microscopy Sciences (Fort Washington, PA, USA). After fixation, samples were washed twice in ice-cold $0.1 \mathrm{M}$ cacodylate buffer. Samples collected offshore 
were held on ice in buffer, after the second wash, for return to the Iaboratory. Specimens were then postfixed in $1 \%$ osmium tetroxide for $1 \mathrm{~h}$, dehydrated for 2 periods of $5 \mathrm{~min}$ in each of $30,50,70,80$, and $95 \%$ ethanol and then placed in 4 changes of $100 \%$ alcohol for 15 min each. This was followed by immersion in 2 changes, for 5 min each, of propylene oxide. Then the specimens were placed for $1 \mathrm{~h}$ in $50 \%$ Spurr's epoxy (Polysciences, Warrington, PA; standard mix) in propylene oxide before infiltration for $1 \mathrm{~h}$ in each of 2 changes of $100 \%$ Spurr's. Tissues were then embedded in Beem capsules, and incubated overnight at $60^{\circ} \mathrm{C}$. Semi-thin sections of epoxy-embedded tissue were cut and stained with toluidine blue for light microscopy. Thin sections were stained with $3 \%$ uranyl acetate for $15 \mathrm{~min}$, and $2.5 \%$ lead citrate for $3 \mathrm{~min}$, and examined with a Zeiss 10 transmission electron microscope. Transmission electron microscopic images were evaluated in parallel with study of the light microscopic images of the same or equivalent structures in semi-thin and paraffin embedded sections.
Age determination. For fish caught in 1989 and 1990 a sample of scales was scraped from the dorsum of the caudal peduncle of each individual. Age was estimated by counting growth rings on these scales.

\section{RESULTS}

Fish from the relatively unpolluted waters of Georges Bank and Scorton Creek were examined to provide a reference for interpreting conditions of fish from Boston. The hepatocyte and preductular histology was as described previously (Bodammer \& Murchelano 1990) (Figs. 1a \& 2a). Livers of juvenile fish from Scorton Creek were similar, albeit with increased hepatocyte basophilia.

\section{Centrotubular vacuolation}

Vacuolation was first evident in fish of 100 to $200 \mathrm{~mm}$ total length from Deer Island Flats. The microvillar
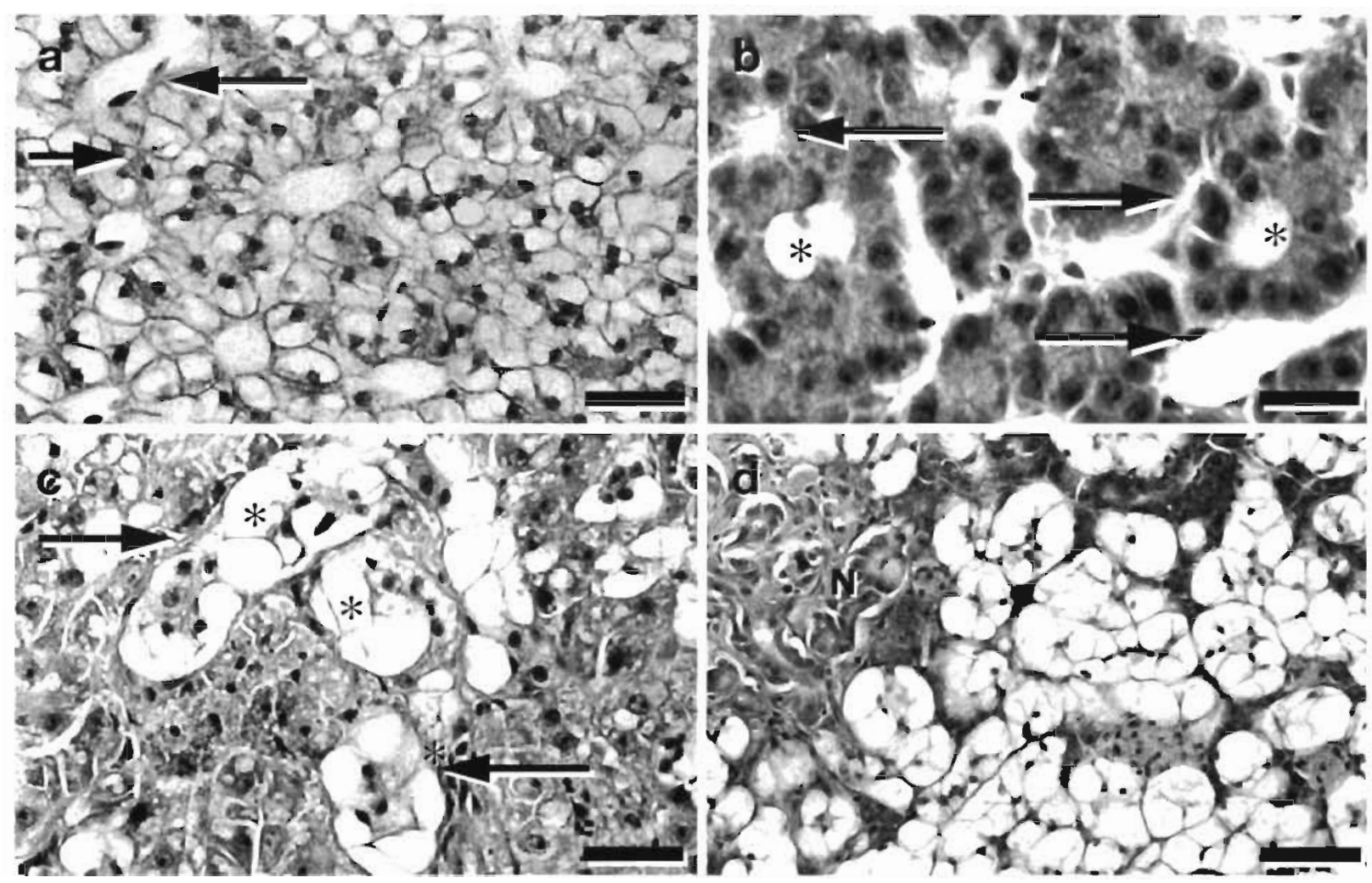

Fig. 1. Pleuronectes americanus. Histological stages of hydropic vacuolation in winter flounder liver. Hematoxylin and eosin stain. Adult flounder from (a) Georges Bank and ( $b$ to d) Deer Island Flats, Boston Harbor. Long arrows depict edge of hepatic tubule and vascular sinusoids. (a) Normal. Arrows show hepatic sinusoids. Hepatocyte cytoplasm lacks basophilia, being lipid and glycogen rich. Bile ducts and ductules are rare. Bar $=25 \mu \mathrm{m}$. (b) Centrotubular vacuolation. Arrows show hepatic sinsoids. (*) Centrotubular vacuolated cells. Bar $=15 \mu \mathrm{m}$. (c) Tubular vacuolation. Arrows show hepatic sinusoids. Entire tubules are vacuolated $(*) . B a r=30 \mu \mathrm{m}$. (d) Focal vacuolation bordering a cholangiocellular carcinoma $(\mathrm{N}) . \mathrm{Bar}=40 \mu \mathrm{m}$ 

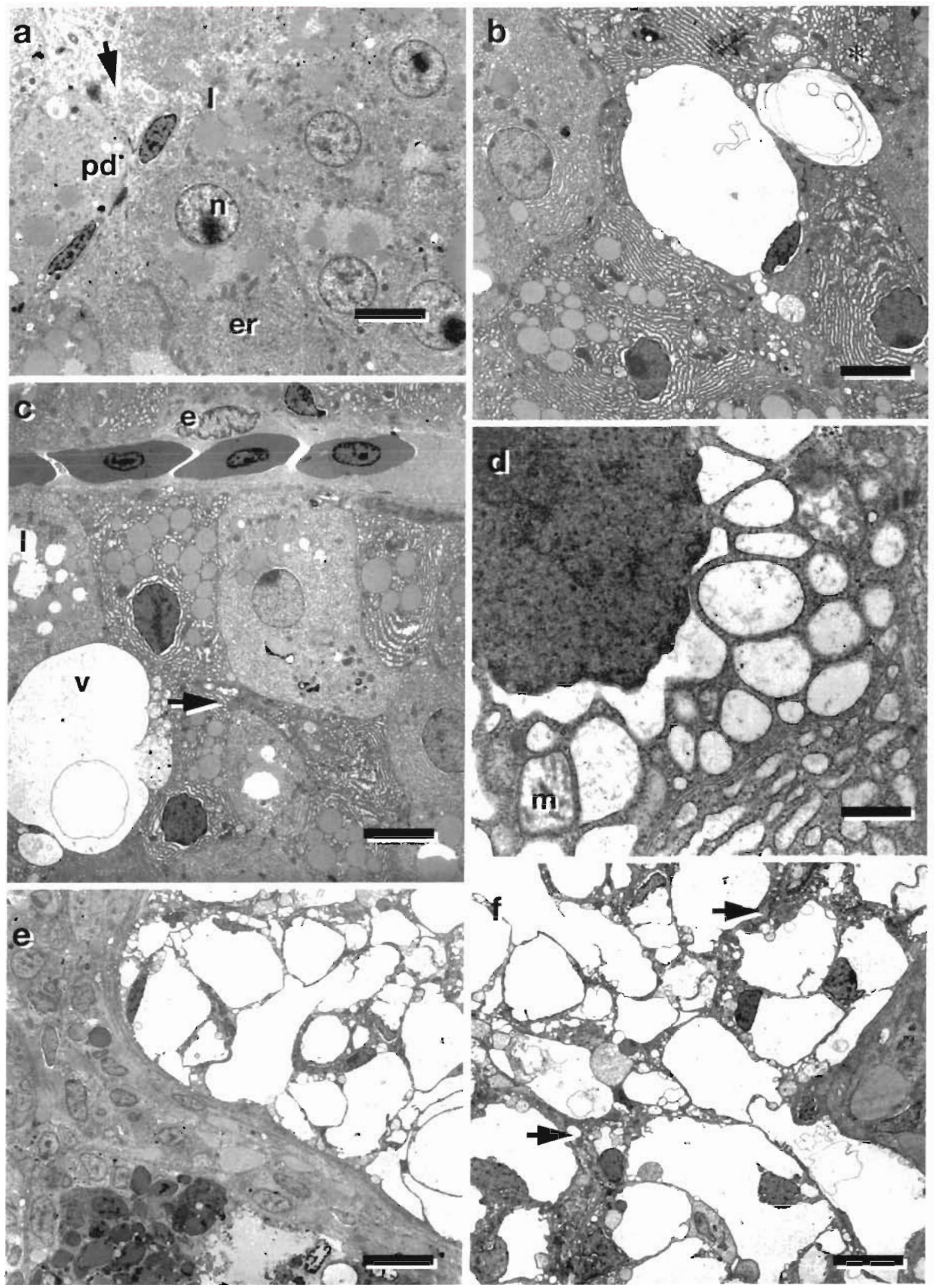
Fig. 2. Pleuronectes americanus. Hepatic ultrastructure of winter flounder from (a) Georges Bank and (b to f) Deer Island Flats, Boston Harbor). Uranyl acetate and lead citrate stain. (a) Normal: Hepatocyte nuclei are circular in section with a prominent nucleolus (n). Hepatocyte cytoplasm contains lipid droplets (l), normal rough endoplasmic reticulum (er) and normal mitochondria. The biliary preductule (pd) is formed by microvillous apices of hepatocytes (arrow) and by fingers of preductular cell cytoplasm. The preductular nucleus is small, ovoid and electron dense in comparison to the hepatocyte nucleus. Bar $=5 \mu \mathrm{m}$. (b) Hepatocytes and preductular cells of a winter flounder with centrotubular vacuolation. The electron-dense ovoid nucleus typical of a preductular cell with its enormously dilated perinuclear space and an adjacent vacuole are seen in the center of the hepatic tubule as shown by their proximity to cellular junctions $(*)$ and a lack of contiguity with any vascular structures. Bar $=$ $6 \mu \mathrm{m}$. (c) The process of vacuolation. A large vacuole (V) fills the center of the hepatic tubule. Smaller vacuoles and dilated mitochondria appear to be in the process of enlarging the main vacuole further. A biliary canaliculus with microvillar border (arrow), hepatocytes undergoing early vesicular change and endothelia (e) are also present. The identity of the vacuolated cell is unclear from this picture. The voids (l) within the larger lipid droplets are an artifact commonly seen following a loss of lipid during processing. Bar $=3 \mu \mathrm{m}$. (d) Hepatocyte apparently undergoing vacuolation by extreme dilation and vesiculation of the cisternal space of the endoplasmic reticulum. The location of the fluid accumulation is shown to be within the cisternae of the endoplasmic reticulum, by the presence of ribosomes on the outside of the membranes bounding the vesicles. A swollen mitochondrion (m) is also present. Bar $=0.4 \mu \mathrm{m}$. (e) Tubular stage of vacuolation. The entire tubule is vacuolated, and ensheathed in fibroblasts. An aggregation of macrophages is evident. Bar $=4 \mu \mathrm{m}$. (f) Focal vacuolation. There is a lack of tubular symmetry. This stage is characterized by large vacuoles, pleomorphic nuclei, numerous cellular junctions (arrows) and multiple smaller vacuoles and vesicles in various stages of formation and disintegration. Bar $=4 \mu \mathrm{m}$

borders of the biliary canaliculi in these fish appeared normal. In contrast the biliary preductules were abnormal. Vacuolation appeared as single and paired cells replacing the biliary preductular space (Figs. 1b, 2a $\& 3 b)$. Ultrastructurally, the process of vacuolation in these cells (Fig. 2b) involved progressive ballooning of the dilated endoplasmic reticulum, the perinuclear space and mitochondria. As these dilated structures increased in size, they appeared to coalesce, forming a single vacuole that occupied the majority of the cell. The vacuoles were filled with electron-lucent fluid which contained a diffuse, floccular, moderately electron-dense material. Histochemical studies of intravacuolar fluid gave negative results for glycogen, iron, nucleic acids, and protein. The images presented here rule out the presence of lipid, and thus it seems likely that the primary constituents are water and electrolytes, with flocculent cell debris.

Fig. 3. Pleuronectes americanus. Schematic drawings of the progressive nature of hydropic vacuolation that convey the structural relationships between each cell type involved. Vascular and perivascular structures have been omitted. (a) A normal tubule of hepatocytes. The central biliary canaliculus drains into the biliary preductule which is partially lined by small preductular epithelial cells. (b) Centrotubular vacuolation. The first stage involves hydropic vacuolation of individual preductular cells in the center of the tubule, and then proceeds to involve a series of preductular cells. (c) Tubular vacuolation. The process of hydropic vacuolation has now spread to involve the entire tubule. Fibroplasia surrounding the tubule is common. (d) Focal vacuolation. These grossly visible foci of hydropically vacuolated cells are presumably formed by the total vacuolation of an area of hepatocytes and biliary epithelia a
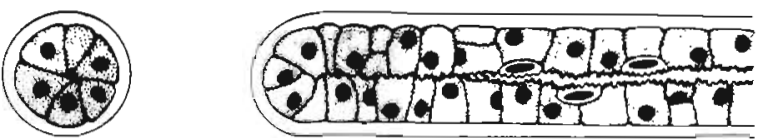

b
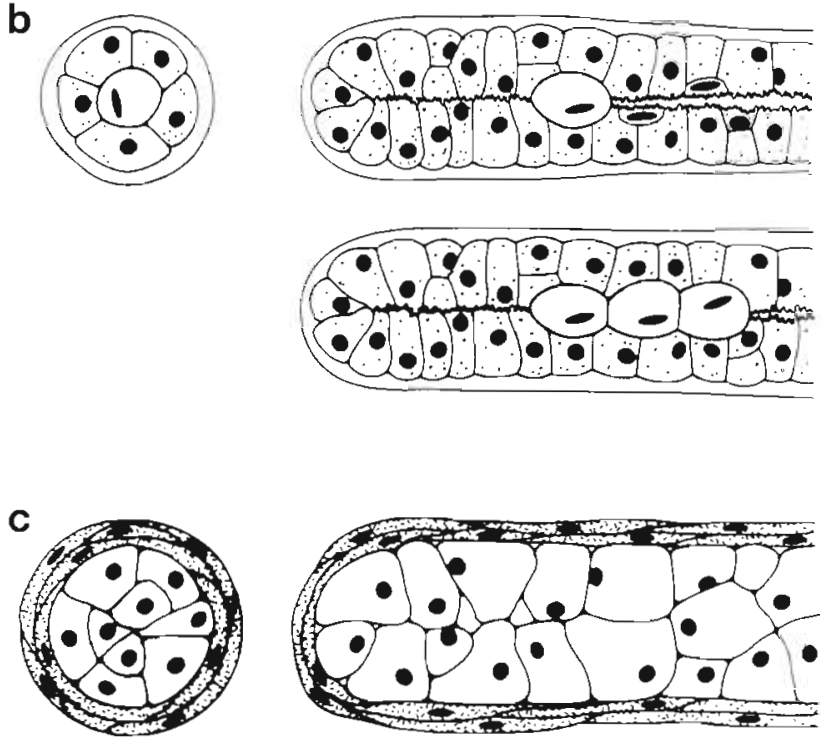

d

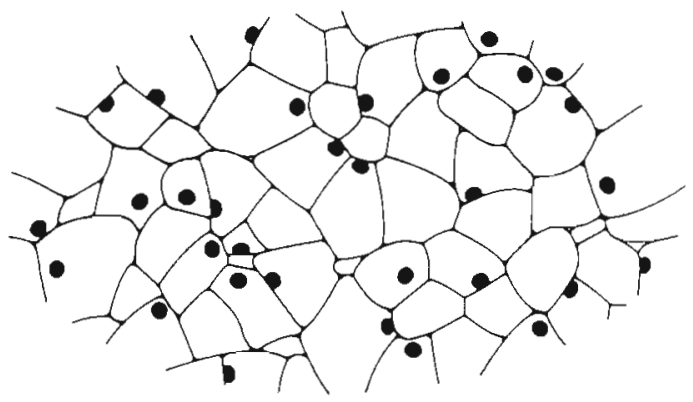


In the vacuolated cells the nucleus and residual cytoplasm appeared only at the cell margin (Fig. 2b). The nucleus of the cell had an oval shape, often flattened on one side, and was electron dense. The nuclear chromatin, when present in the plane of section, appeared like that of normal non-vacuolated preductular cells confirming our previous observation (Moore et al. 1989) that vacuolated centrotubular cells were primarily abnormal preductular cells. Thus, these single vacuolated cells were surrounded by hepatocytes (Fig. 1b), with many cellular junctions between centrotubular vacuolated cells and adjacent hepatocyte apices. However, these cells were significantly enlarged in their cytoplasmic volume as compared to normal flounder preductular cells and they filled and expanded the preductular lumen.

\section{Tubular vacuolation}

Vacuolated centrotubular cells often were ringed by hepatocytes showing micro-vesiculation of the endoplasmic reticulum. One specimen contained a preductule that was grossly swollen by the ballooning vacuolated preductular celli an adjacent hepatocyte showed clear evidence that the fluid accumulation in the endoplasmic reticulum was in the cisternal space (Fig. 2d). In the livers of more severely affected fish, abnormally vacuolated cells of hepatic tubules were seen in curvilinear arrays or cords, many cells long, though only 1 to 4 cells wide (Figs. 1c \& 2e). These cords of vacuolated cells seemed to run into partially vacuolated bile ductules. Greatly thickened preductular fibrotic tissue was noted around these vacuolated tubules and appeared to extend as fine branches from a biliary tree ensheathed in fibrous tissue. The transition between vacuolated bile ducts and the vacuolated tubules was gradual. Ultrastructurally, entire hepatocyte tubules were seen to be filled with vacuolated cells having large ballooned vacuoles that appeared to force the nucleus and residual cytoplasm to the cell margin (Fig. 2e).

\section{Focal vacuolation}

In some fish vacuolated cells also appeared in aggregations of several hundred cells, forming nodules (Figs. 1d \& 2f) that were visible grossly (Moore \& Stegeman 1994). In addition these fish usually contained other moderate to advanced hepatic lesions. Ultrastructurally, the vacuolated cells in these large clusters were similar to those described above with each cell containing the same large vacuole, with flocculent material that pushed the small nucleus and remaining cytoplasmic organelles to the edge of the cell. In one case vacuoles were also apparent in the nucleus of a vacuolated cell. Within the large nodules of vacuolated cells there were often islands of small, apparently undifferentiated, non-vacuolated basophilic cells. Vascular structures were rare within foci of vacuolation.

These histological and ultrastructural observations are illustrated schematically in Fig. 3. Other histological changes such as macrophage aggregation have been described previously (Moore et al. 1996).

\section{Age/length frequencies and persistence of vacuolated cells}

There were trends of increasing lesion frequency with increasing body length (Fig. 4) and age (Fig. 5). For each length and age class that exhibited pathological change, centrotubular vacuolation was more common than tubular vacuolation, which in turn was more frequent than focal clusters of vacuolated cells. Neoplasia was absent from fish less than $5 \mathrm{yr}$ old. A low frequency of non-neoplastic lesions was seen in young fish less than $300 \mathrm{~mm}$ in length. Marked increases in lesion frequency (Fig. 4) were seen after the onset of sexual maturity (usually seen in fish longer

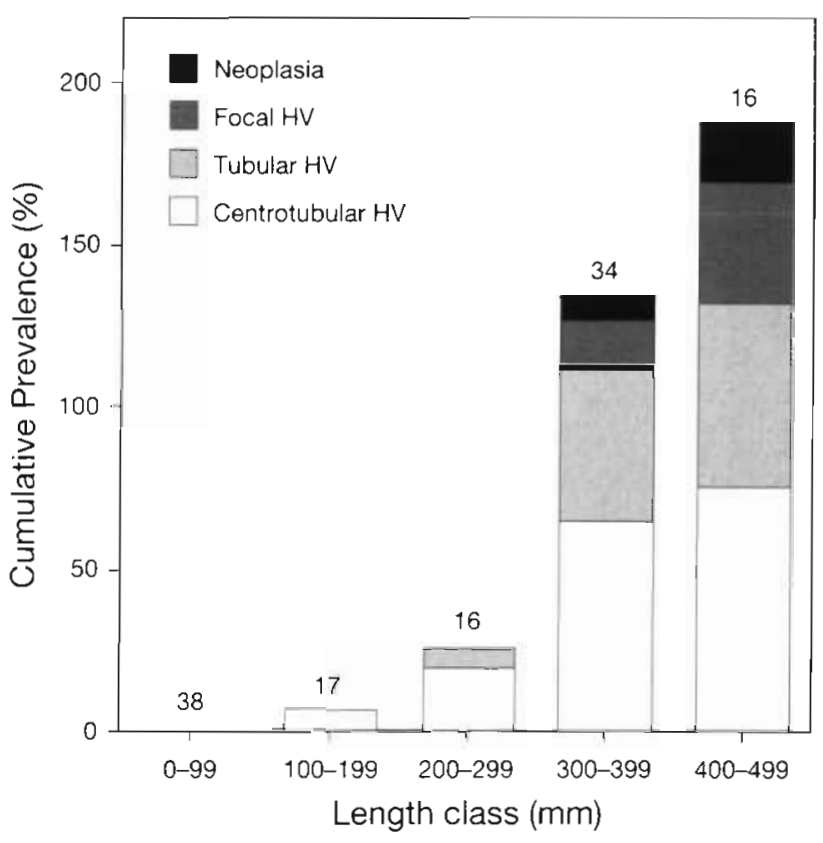

Fig. 4. Pleuronectes americanus. Cumulative prevalence (\%) of the 3 stages of hydropic vacuolation (HV) and of liver neoplasia in 5 winter flounder size classes from Deer Island Flats Ages were not available for fish described in this figure. Fish in the 0 to $199 \mathrm{~mm}$ size classes were caught through the summer and fall of 1987 . Fish in the 200 to $499 \mathrm{~mm}$ size classes were caught on March 18, 1988 


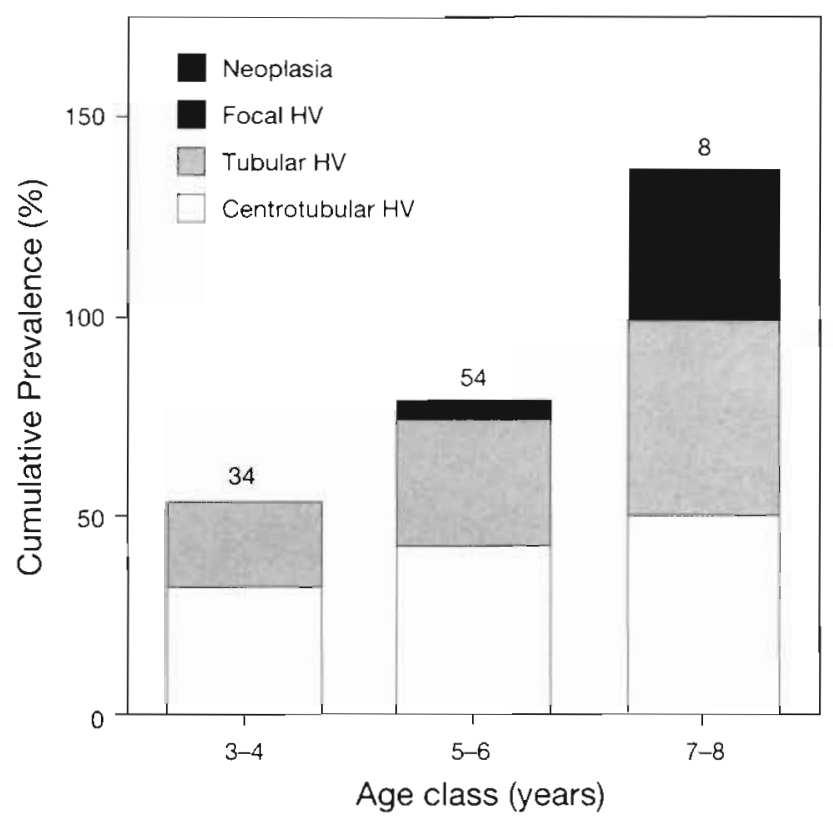

Fig. 5. Pleuronectes americanus. Cumulative prevalence (\%) of the 3 stages of hydropic vacuolation (HV) and of liver neoplasia in 3 winter flounder age classes collected from Deer Island Flats on April 30, 1990

than $300 \mathrm{~mm}$ ). No obvious differences were observed in neoplastic or non-neoplastic lesion prevalence between males and females (Table 1). Lesions of any type were absent in young of the year fish $(\leq 100 \mathrm{~mm})$.

The persistence of vacuolated lesions was evaluated in winter flounder from Deer Island held for $5 \mathrm{mo}$ in clean water and fed clean food. There was no significant difference between freshly caught and depurated fish in the prevalence of centrotubular, focal or vacuolated cell lesions (Table 2).

\section{DISCUSSION}

Hydropic vacuolation is a pervasive, often severe condition in liver of winter flounder from chemically contaminated habitats. Despite past descriptions of this lesion, there has been no systematic staging of the lesion, comparison of the cells involved at each stage, or determination of whether the lesion is involved in tumorigenesis. In this study we define and illustrate the progression of hydropic vacuolation through 3 stages. Increasing prevalence of each stage is correlated positively with increasing age and length. We present evidence that biliary cells and probably hepatocytes are involved in the condition. We also show data consistent with the hypothesis that hydropic vacuolation persists in the absence of ongoing exposure to exogenous chemical insult.
Table 1. Pleuronectes americanus. Prevalence (\%) of hydropic vacuolation and liver neoplasia in winter flounder liver from Deer Island Flats in the years 1985 through 1990. There was no significant difference between gender for any lesion prevalence $\left(\chi^{2}>0.05\right)$. These lesions were absent in 50 adult flounder examined from Georges Bank

\begin{tabular}{|c|c|c|c|c|}
\hline $\begin{array}{l}\text { Gender } \\
\text { (sample size) }\end{array}$ & $\begin{array}{l}\text { Centro- } \\
\text { tubular HV }\end{array}$ & $\begin{array}{c}\text { Tubular } \\
\text { HV }\end{array}$ & $\begin{array}{l}\text { Focal } \\
\text { HV }\end{array}$ & $\begin{array}{c}\text { Liver } \\
\text { neoplasia }\end{array}$ \\
\hline Females (198) & 55.6 & 43.9 & 13.6 & 9.6 \\
\hline Males (87) & 59.8 & 46.0 & 14.9 & 11.5 \\
\hline
\end{tabular}

Table 2. Pleuronectes americanus. Prevalence (\%) of hydropic vacuolation (HV) and liver neoplasia in winter flounder liver from Deer Island Flats, Boston Harbor, after maintenance on clean food in clean water prior to sampling

\begin{tabular}{|lcccc|}
\hline $\begin{array}{l}\text { Time since removal } \\
\text { from Boston Harbor } \\
\text { (sample size) }\end{array}$ & $\begin{array}{c}\text { Centro- } \\
\text { tubular } \\
\text { HV }\end{array}$ & $\begin{array}{c}\text { Tubular } \\
\text { HV }\end{array}$ & $\begin{array}{c}\text { Focal } \\
\text { HV }\end{array}$ & $\begin{array}{c}\text { Liver } \\
\text { neo- } \\
\text { plasia }\end{array}$ \\
\hline$\leq 6 \mathrm{~d}(52)^{\text {" }}$ & 63.5 & 65.4 & 13.5 & 5.8 \\
5 mo (52) & 73.0 & 76.9 & 21.1 & 11.5 \\
a Caught Mar 18, 1988 and killed within 6 d & \\
${ }^{\mathrm{C} C a u g h t}$ Apr 21,1987 and killed Sep 25, 1987 & \\
\hline
\end{tabular}

\section{Stages of hydropic vacuolation}

Bodammer \& Murchelano (1990) reported on the hepatocyte ultrastructure of 2 winter flounder from Boston Harbor. Both fish showed vacuolation similar to the tubular vacuolation stage as defined in this study. They incorrectly cite Moore et al. (1989) as stating that vacuolated cells are all preductular. In the present study we confirm that the first cell type to undergo vacuolation is centrotubular (Fig. 1) and preductular (Fig. 2b) in origin. The early vacuolated cells fit criteria for preductular cells as defined by (Hampton et al. 1988). These criteria include central location within the hepatic tubule, nuclear morphology, and the presence of many cellular junctions. However, we have also demonstrated that cells occupying the normal location of hepatocytes appear to be vacuolated in the second or tubular stage of the process (Fig. $2 \mathrm{c}$ and d). A question that remains is whether tubular arrays of vacuolated cells result from 'recruitment' of hepatocytes into the vacuolation process, from the proliferation of centrotubular vacuolated cells, or adjacent stem cells to fill the entire tubule, displacing dying hepatocytes, or from a combination of these 2 processes.

While a stepwise progression from centrotubular vacuolation to tubular vacuolation to grossly visible foci of vacuolated cells is identified in this study, the fate of the vacuolated cells is unknown. It is not known whether the vacuolated cells are in a state that pre- 
cludes replication. The fact that fully vacuolated cells have very few cytoplasmic organelles argues against replication. However, what little cytoplasm the cells do retain appears relatively normal, and their nuclear morphology is essentially unchanged. Further analysis of the identity of vacuolated cells and their peripheral neighbors in the same tubule is essential in an understanding of the generation of tubular vacuolation and, likely, focal alteration.

\section{Possible causes of hydropic vacuolation}

The finding that hydropic vacuolation is common in Boston Harbor fish but not in Georges Bank fish is consistent with the idea that chemicals induce this celiluidr change. Known hepatotoxins are among the compounds occurring in the severely contaminated sediments of Boston Harbor, and in the fish inhabiting those waters. Furthermore, the prevalence of hydropic vacuolation has been shown to be correlated with environmental exposure to aromatic and halogenated hydrocarbons (Johnson et al. 1992). There has been no fully documented experimental induction of hydropic vacuolation, although there is a brief mention of the lesion appearing after exposure of winter flounder to contaminated sediment (Gardner et al. 1991). The basis for vesiculation involves an ingress of water (Ghadially 1988). Factors known to induce vesiculation of hepatic endoplasmic reticulum in other systems include artifactual hypotonicity during tissue processing, starvation, hypoxia and cholestasis (David 1964, Smuckler \& Arcasoy 1969). Artifact is unlikely in the appearance of hydropic vacuolation in winter flounder as the fixative used was hypertonic, and no comparable changes were seen in Georges Bank fish fixed in an identical manner. Likewise, starvation is not likely an issue, as all of the fish, except those held in the laboratory for $5 \mathrm{mo}$, were killed within $48 \mathrm{~h}$ of capture, and many had food in their intestines.

As defined here, hydropic vacuolation is somewhat different from a lesion described as hydropic degeneration, a commonly recognized injury that follows exposure to agents that affect cell fluid tonicity. Hydropic degeneration can be reversible, or lead to cell death, whereas the hydropic vacuolation described here appears not to resolve either in cell death or recovery, but may persist, an idea consistent with our depuration data, and increase in prevalence with time, on the basis of our field data. The role of cholestasis in the development of these changes is unclear. Histologically, dilated and hyperplastic bile ducts and ductules were common in fish from Boston. These structures often accumulated bile fluid within them. However, classical ultrastructural signs of canalicular cholestasis, such as the presence of granular and vesicular secretions in dilated canaliculi that have lost their microvillar border (Phillips et al. 1987), were not observed, although in some fish the canalicular microvilli were somewhat reduced.

The vacuolated cells could be in a state of cellular diapause, surviving in a hepatotoxic cellular milieu. These diseased liver tissues may be somewhat hypoxic, given the marked reduction in the prominence of vascular sinusoids, and the almost total absence of sinusoids from many of the foci of vacuolated and neoplastic cells. It is notable that the first cell type to undergo vacuolation is the cell farthest from the capillary bed, namely the biliary preductular cell (Hinton \& Pool 1976). This cell may be most like a hepatic epithelial stem cell, it other investigators (Hampton et al. 1988, Nunez et al. 1990) are correct in presuming preductular cells to be oval cell equivalents. Thus, the reason(s) for the development of vacuolated cells remain unclear, although exposure to chemical contaminants is likely to be the ultimate cause. It should be noted here that the oxygen tension of the water at the field stations and in laboratory systems has been normal whenever measured. It was not measured at the time of collection in all instances.

\section{Role of hydropic vacuolation in the development of neoplasia}

Does hydropic vacuolation represent a chronic injury resulting from exposure to hepatotoxins that always progresses to cell death, or is it some form of cytotoxin resistant epithelial phenotype, arising from hepatocytes and cholangiocytes, or from their common stem cell? Hydropically vacuolated cells have been described by some as apoptotic (Carr et al. 1991). The ultrastructural studies described here fail to show any structures associated with vacuolated cells that in any way correspond to previously described apoptotic bodies in mammals (Wyllie et al. 1980). Furthermore, this study is consistent with the idea that hydropically vacuolated cells appear to persist, or recurrently develop, for a period of months after removal of the fish from a contaminated habitat. This is in distinct contrast to apoptotic cells that have a half-life of a few hours in mammals (Wyllie et al. 1980). The probable persistence strongly indicates that vacuolation does not necessarily progress to cell death if at all.

Murchelano \& Wolke (1985) speculated that the vacuolation process might be irreversible, with some vacuolated cells progressing to necrosis, and that surviving cells may be committed to neoplasia (Murchelano 1990). The depuration experiment described above (Table 2) shows a degree of stability in the 
vacuolated phenotype, independent of continued exposure to chemicals in the environment, unless removal to clean water and food allowed an ongoing release of hydrophobic cytotoxins from lipid stores in the fish. Bodammer \& Murchelano (1990) concluded that they were 'not.. successful in describing a population(s) of hepatotoxin resistant cells'. On the contrary, we believe that the vacuolated cells that they and we have described may be such a population, and that the depuration data presented here are consistent with the idea that these cells persist even in the absence of ongoing exposure to hepatotoxins.

Several lines of evidence suggest that vacuolated cells, or adjacent stem cells, have the potential to proliferate. We have previously suggested that vacuolated cells are an active part of the proliferative process (Moore et al. 1989), although mitotic figures have not been described in vacuolated cells. We have shown them and/or their immediate small ovoid neighbors to have the capacity to synthesize DNA in the S-phase of the mitotic cycle (Moore \& Stegeman 1992), to express proliferating cell nuclear antigen (Moore et al. unpubl. data) and to express levels of ornithine decarboxylase, a key regulatory enzyme involved in cell proliferation (Koza et al. 1993). The possibility that vacuolated cells, or their immiedate neighbors, may be involved in transformation to various neoplastic phenotypes is highly intriguing. Vacuolated cells are found within and around foci of all types of neoplasia (Moore \& Stegeman 1994). Which came first? Many foci of vacuolated cells are interspersed with small islands of small non-vacuolated basophilic cells. Other vacuolated cell foci contain foci of neoplasia. At the extreme, some neoplastic foci examined in this study had a peripheral ring of vacuolated cells which itself was surrounded by more normal parenchyma. These may have been large foci of vacuolated cells, almost entirely overgrown by neoplastic cells. On the other hand, one might speculate that the vacuolated cells were in some way part of the advancing edge of the neoplasm, and these cells with time acquired the transformed, atypical neoplastic phenotype.

In summary, the abnormally vacuolated cells in winter flounder liver arise first in biliary preductular cells. Vacuolation is a progressively worsening condition subsequently probably involving hepatocytes. The vacuolated cells are probably persistent, and may be proliferative. Vacuolated cells often are intimately associated with neoplasia and linked to contaminants. The molecular changes associated with vacuolation and role of vacuolated cells in neoplastic process are unknown. Further understanding of the progression and consequences of vacuolation must await the development of an experimental system to generate these cellular changes in vivo or in vitro in the labora- tory. Such studies would aid our understanding of the pathogenesis of hepatic neoplasia in fish, as a phylogenetic-precursor model for mammalian hepatocarcinogenesis. Finally, the definition of the 3 stages of this lesion now allows the prevalence of each stage of hydropic vacuolation to be used to monitor long-term toxicological changes associated with upgraded coastal sewage management in the Massachusetts Bays (Moore et al. 1996).

Acknowledgements. We gratefully acknowledge Robert Golder for providing the drawings in Fig. 3, and Louis Kerr for technical support for the transmission electron microscope. The depurated fish were provided by Robert Murchelano and maintained by Fred Nichy. The fish from Georges Bank were collected by Emily Monosson and the National Marine Fisheries Service, and the slides from the New England Aquarium were loaned by William Robinson. Age estimates were provided by Jay Barnett. David Hinton and Clyde Dawe provided constructive advice. Funded in part by PHS Grant CA44306, The Donaldson Charitable Trust and Woods Hole Oceanographic Institution Education Office. WHOI Contribution \# 9468 .

\section{LITERATURE CITED}

Bodammer JE, Murchelano RA (1990) Cytological study of vacuolated cells and other aberrant hepatocytes in winter flounder from Boston Harbor. Cancer Res 50:6744-6756

Boehm PD, Hirtzer P (1982) Gulf and Atlantic survey for selected organic pollutants in finfish. NOAA Tech Mem, Woods Hole, MA, NMFS-F/NEC-13:111

Carr RS, Hillman RE, Neff JM (1991) Field assesment of biomarkers for winter flounder. Mar Pollut Bull 22:61-67

David H (1964) Submicroscopic ortho- and patho-morphology of the liver. Pergamon Press, Oxford, MD

Gardner GR, Yevich PP, Harshbarger JC, Malcolm AR (1991) Carcinogenicity of Black Rock Harbor sediment to the Eastern oyster and trophic transfer of Black Rock Harbor carcinogens from the blue mussel to the winter flounder. Environ Health Perspect 90:53-66

Ghadially FN (1988) Ultrastructural pathology of the cell and matrix. Butterworths, London

Hampton JA, Lantz RC, Goldblatt PJ, Lauren DJ, Hinton DE (1988) Functional units in rainbow trout (Salmo gairdneri) liver: II. The biliary system. Anat Rec 221:619-634

Hinton DE, Pool CR (1976) Ultrastructure of the liver in channel catfish Ictalurus punctatus (Rafinesque). J Fish Biol 8:209-219

Ito S, Karnovsky $M$ (1968) Formaldehyde-glutaraldehyde fixatives containing trinitro compounds. J Cell Biol 39 $168 \mathrm{~A}-169 \mathrm{~A}$

Johnson LL, Stehr CM, Olson OP, Myers MS, McCain BB, Chan SL, Varanasi U (1992) National Status and Trends program, National Benthic Surveillance Project, Northeast Coast. Fish histopathology and relationships between lesions and chemical contaminants $(1987-9)$. NOAA Technical Memorandum. NMFS-NWFC-4

Johnson LL, Stehr CM, Olson OP, Myers MS, Pierce SM, Wigren CA, McCain BB, Varanasi U (1993) Chemical contaminants and hepatic lesions in winter flounder (Pleuronectes americanus) from the northeast coast of the United States. Environ Sci Technol 27:2759-2771 
Koza RA, Moore MJ, Stegeman JJ (1993) Elevated ornithine decarboxylase activity and cell proliferation in neoplastic and vacuolated liver cells of winter flounder (Pleuronectes americanus). Carcinogenesis 14:399-405

Luna LG (1968) Manual of histologic staining methods of the Armed Forces Institute of Pathology. McGraw-Hill, New York

Moore MJ (1991) Vacuolation, proliferation and neoplasia in the liver of winter flounder, Pseudopleuronectes americanus, from Boston Harbor, Massachusetts. Woods Hole Oceanographic Institution, Tech Rep 91-28:1-268

Moore MJ, Shea D, Hillman RS, Stegeman JJ (1996) Trends in hepatic tumors and hydropic vacuolation, fin erosion, organic chemicals and stable isotope ratios in winter flounder from Massachusetts, USA. Mar Pollut Bull 32: $458-470$

Moore MJ, Smolowitz RM, Leavitt DF, Stegeman JJ (1995) Evaluation of chemical contaminant effects in the Massachusetts Bays - final report Massachusetts Bays Program, 100 Cambridge St, Boston, MA

Moore MJ, Smolowitz R, Stegeman JJ (1989) Cellular alterations preceding neoplasia in (Pseudopleuronectes americanus) from Boston Harbor. Mar Environ Res 28:425-429

Moore MJ, Stegeman JJ (1990) Pathogenesis of hepatic neoplasia in Boston harbor winter flounder (Pseudopleuronectes americanus). Proc Am Assoc Cancer Res 31:87

Moore MJ, Stegeman JJ (1992) Bromodeoxyuridine uptake in hydropic vacuolation and neoplasms in winter flounder

Editorial responsibility: Thomas Braunbeck,

Heidelberg, Germany liver. Mar Environ Res 34:13-18

Moore MJ, Stegeman JJ (1994) Hepatic neoplasms in winter flounder, Pleuronectes americanus, from Boston Harbor, Massachusetts, USA. Dis Aquat Org 20:33-48

Murchelano RA (1990) Fish health and environmental health. Environ Health Perspect 86:257-259

Murchelano RA, Wolke RE (1985) Epizootic carcinoma in the winter flounder, Pseudopleuronectes americanus. Science 228.587-589

Myers MS, Stehr CS, Olson OP, Johnson LL, McCain BB, Chan SL, Varanasi U (1994) Relationships between toxicopathic hepatic lesions and exposure to chemical contaminants in English sole (Pleuronectes vetulus), starry flounder (Platichthys stellatus), and white croaker (Genyonemus stellatus) from seleted marine sites on the Pacific Coast, USA. Environ Health Perspect 102:200-215

Nunez O, Hendricks JD, Fong AT (1990) Inter-relationships among aflatoxin $\mathrm{B}_{1}\left(\mathrm{AFB}_{1}\right)$ metabolism, DNA-binding, cytotoxicity, and hepatocarcinogenesis, in rainbow trout Oncorhynchus mykiss. Dis Aquat Org 9:15-23

Phillips MJ, Latham PS, Poucell S (1987) Electron microscopy of liver diseases. In: Schiff L, Schiff ER (eds) Diseases of the liver, 6th edn. Lippincott, Philadelphia, PA, p 56-58

Smuckler EA, Arcasoy M (1969) Structural and functional changes of the endoplasmic reticulum of hepatic parenchymal cells. Int Rev Exp Pathol 7:305-418

Wyllie AH, Kerr JFR, Currie AR (1980) Cell death: the significance of apoptosis. Int Rev Cytol 68:251-310

Submitted: January 2, 1997; Accepted: July 19, 1997 Proofs received from author(s): September 23, 1997 